\title{
SERVICE AS PART OF THE COUNTRY'S ECONOMY
}

\author{
Marina Shipulya ${ }^{1}$ \\ Tatiana Tolmacheva ${ }^{2}$
}

DOI: https://doi.org/10.30525/978-9934-588-52-5-30

In the modern world, service has ceased to be that segment of the economy that throughout the history of mankind has served only domestic needs. Today, this area is the most important basis for the economy of post-industrial society.

The history of the development of the service goes into the distant past. In the early stages, the social provision of services was underdeveloped, however, with the progressive development of society, the service sector was fully formed and became an integral sector of the country's economy.

Service is a special type of human activity that focuses on meeting the needs of customers by offering certain services. Under the service refers to a set of measures aimed at meeting the needs of customers and having a specific cost [2].

The main objective of companies in customer service is to satisfy their needs. Service is also able to influence the formation of needs.

The main components of service activities are considered to be the contractor, consumer, service conditions, the service process and its result, that is, the service [4, p. 1107].

In modern society, it is customary to attribute several large sectors of the economy to service activities: trade, capital, motor transport, healthcare, the entertainment and sports industry, as well as the fields of science, education and management.

Service is given to certain organizations at a professional level, for which specialized knowledge, professional skills and appropriate special equipment are needed.

Service experts should be in demand on the labor market. They study service operations and organize the company's activities for the highest satisfaction of human needs. It is worth noting that modern society is constantly on the move, people's needs are regularly changing and increasing. It follows that service enterprises will always be popular, and they cannot do without professional service [3, p. 80].

There are many classifications of varieties of services. However, the following types are considered the most common at the moment:

\footnotetext{
${ }^{1}$ Federal State Autonomous Educational Institution

of Higher Education «North Caucasus Federal University», Russian Federation

${ }^{2}$ Federal State Autonomous Educational Institution

of Higher Education «North Caucasus Federal University», Russian Federation
} 
1. Production.

2. Distribution.

3. Professional.

4. Consumer.

5. Social [1, p. 155].

Previously, each type of service was studied separately as a special area ofactivity. And the whole service was presented as a combination of these types of services. All classification features make it possible to analyze the various functions of service activities in society.

Thus, the service makes a concrete contribution to the country's economy, enhancing social security and contributing to an increase in the level and quality of life of the population. An actively emerging service sector is considered a significant condition for enhancing entrepreneurship and ensuring employment.

\section{References:}

1. Kushnareva, I. V., Zhidkov, V. E., Alekhine, E. S., \& Gornostaeva, J. V. (2013). Service activities: a textbook for undergraduate students in the direction 100100.62 Service. Institute of Service and Entrepreneurship (branch) DGTU. Moskva; Stavropol: MIRACLE; Stavrolite, 176 p.

2. Savchishina, K. E., \& Sutyagin, V. S. Services in the modern reproductive process of the Russian economy. URL: http://institutiones.com/general/1487-sferauslug-rosijskoj-ekonomiki

3. Smirnova, E. T. (2004). Service activity (introduction to servology): textbook. allowance. Moskva: MGUS, 83 p.

4. Fadeeva, N. V. (2012). Service properties and their suitability for measuring the quality of a service system. Tomsk State University Journal. Tamb. state tech. un-that., vol. 18, no. 4, pp. 1107-1114. 